This item is the archived peer-reviewed author-version of:

The value of government ownership during the global financial crisis

\title{
Reference:
}

Beuselinck Christof, Cao Lihong, Deloof Marc, Xia Xinping.- The value of government ow nership during the global financial crisis Journal of corporate finance - ISSN 0929-1199 - 42(2017), p. 481-493

Full text (Publisher's DOI): https://doi.org/10.1016/J.JCORPFIN.2015.05.002

To cite this reference: $h$ ttp://hdl.handle.net/10067/1269280151162165141 


\title{
The Value of Government Ownership during the Global Financial Crisis
}

\author{
Forthcoming in Journal of Corporate Finance, \\ http://dx.doi.org/10.1016/j.jcorpfin.2015.05.002 \\ Christof Beuselinck \\ IESEG School of Management and LEM \\ Lihong $\mathrm{CaO}^{*}$ \\ Business School of Hunan University \\ University of Antwerp \\ Marc Deloof \\ University of Antwerp and Antwerp Management School \\ Xinping Xia \\ Huazhong University of Science and Technology
}

\footnotetext{
* Corresponding author: Lihong Cao, Business School of Hunan University, China, and University of Antwerp, Belgium; email caolhjy@gmail.com. We would like to thank an anonymous referee, Stephen Christophe, Marc Jegers, Andy Lardon, and Robert Nash (co-editor), as well as participants at the 2012 Corporate Finance Day in Ghent, the 2013 European Financial Management Association Meeting in Reading, and the Conference on Privatization at Wake Forest University for helpful comments and suggestions. Andy Lardon also helped us greatly with the data collection.
} 


\title{
The Value of Government Ownership during the Global Financial Crisis
}

\begin{abstract}
This paper examines the value of government ownership in Europe during the global financial crisis. This crisis was an exogenous shock for European firms, which allows us to observe an out-of-equilibrium effect on the costs and benefits of government ownership. Using a comprehensive sample of 4,737 listed firms in 28 European countries over the period 2005-2009, we find that firms with government ownership experienced a smaller reduction in firm value than firms without government ownership. This effect was driven by firms located in countries where the risk of expropriation by the government is lower, that is, countries with less corruption and better investor protection.
\end{abstract}

Keywords: Government ownership, global financial crisis, firm value, institutional quality, Europe

JEL classification code: G01, G31, G38, H81 


\section{The Value of Government Ownership during the Global Financial Crisis}

\section{Introduction}

In the wave of privatization that began in the United Kingdom in the 1980s and spread across the globe during the 1990s, governments all over the world sold large blocks of their ownership positions to the private sector (Megginson and Netter, 2001). However, government ownership of publicly traded companies remains pervasive around the world and the debate of government involvement in public companies has been reopened in the wake of the recent global financial crisis, since governments in many industrialized, market-oriented economies worldwide have been taking on equity stakes as part of rescue packages (Nanto, 2009; The Economist 2012).

As shareholders, governments can use their voting rights to influence business decisions. This can be detrimental to firm value for several reasons. Governments may use state-owned enterprises (SOEs) to try to maximize social welfare rather than firm value (Vickers and Yarrow, 1991) and may be pressured by specific interest groups, such as labor unions, to pursue socially desirable objectives, such as maintaining high levels of employment (Bennedsen, 2000; Boycko et al., 1996; Laffont and Shleifer, 1998; Laffont and Tirole, 1991). Furthermore, politicians may abuse their power to derive personal benefits from SOEs (John et al., 2008; Shleifer, 1998; Shleifer and Vishny, 1994) and the government might give managers of SOEs considerable discretion to pursue their own agendas. Since the government is unlikely to allow SOEs to go bankrupt, the discipline enforced on private firms by capital 
markets and the threat of financial distress matter less for SOEs (Laffont and Tirole, 1991; Megginson and Netter, 2001; Schmidt, 1991). The incentives of politicians to monitor the managers of SOEs are rather poor anyway, because political fortunes are typically not sensitive to the performance of SOEs (Vickers and Yarrow, 1991).

Government ownership may also bring benefits to firms. Government ownership can help firms to cope with external uncertainties (Agrawal and Knoeber, 2001; Collins, 2009; Hillman et al.; Pfeffer and Salancik, 1978) and can facilitate access to financial resources such as bank loans (Faccio, 2006; Khwaja and Mian, 2005) by providing explicit and implicit guarantees to secure debt financing. A government ownership stake may signal the government's commitment to bail out the firm in times of economic distress, thereby minimizing the risk of default (Borisova and Megginson, 2011; Borisova et al., 2012b) and allowing firms to take on more risk (Boubakri et al., 2013b). This may ultimately increase the value of government-owned firms.

A number of studies have found that government ownership (Brandt and $\mathrm{Li}, 2003$ ) and political connections (e.g., Boubakri, 2012; Charumilind et al., 2006; Fan et al., 2008; Khwaja and Mian, 2005; Sapienza, 2004) increase access to bank financing. In a similar vein, political connections also increase the likelihood of being bailed out by the government (Faccio et al., 2006). However, this does not seem to increase firm value. Most empirical studies find a negative association between government ownership and firm performance (e.g., Boardman and Vining, 1989; Boubakri and 
Cosset, 1998; Boubakri et al., 2005a; D’Souza et al., 2005; Dewenter and Malatesta, 2001; Gupta, 2005; Megginson et al., 1994). ${ }^{2}$

In the current study, we contribute to the debate about the role of government ownership by analyzing the relation between government ownership and the value of European firms during the global financial crisis of 2008-2009. This crisis was an exogenous shock for European firms, which allows us to observe an out-ofequilibrium effect on the costs and benefits of government ownership. Using the global financial crisis as an exogenous shock and measuring government ownership on a pre-crisis basis eliminates potential simultaneity problems and overcomes endogeneity issues (e.g., Bae et al., 2012; Baek et al., 2004; Lemmon and Lins, 2003; Lins et al., 2013; Mitton, 2002). We test the hypothesis that the shock from the financial crisis - which was not expected by individual firms - affected the costs and benefits of government ownership in a way that led to a net reduction in the cost of government ownership to outside shareholders. We expect that the implicit and explicit government guarantees became more valuable during the crisis, when access to external finance was restricted (Almeida et al., 2011; Duchin et al., 2010) and firms were more likely to fail (Ivashina and Scharfstein, 2010; Lins et al., 2013; Puri et al., 2011). Furthermore, the global financial crisis may have induced governments to forgo the short-term political incentives of diverting firm resources, thus temporarily reducing the costs of government ownership to outside shareholders (Friedman et al., 2003). On the other hand, a crisis might increase expropriation by the government and

\footnotetext{
${ }^{2}$ Two exceptions are the works of Kole and Mulherin (1997), who find that US government stakes in American subsidiaries of German and Japanese firms during World War I did not significantly affect accounting performance, and of Tian and Estrin (2008), who find a U-shaped relation between state shareholdings and corporate value in China.
} 
could exacerbate the inefficiencies of government firms. So it is also possible that the costs of government ownership increased substantially during the crisis.

Since the quality of the institutional environment is an important factor in firm value (La Porta et al., 1998), we expect that country-level corporate governance will have an impact on the changing benefits and costs of government ownership during the crisis. Weak institutions and poor investor protection make it easier for governments to expropriate the firms they control (Borisova et al., 2012a; La Porta et al., 1998; Shleifer, 1998) and falling expected returns increase the incentives for controlling shareholders to expropriate (Johnson et al., 2000). By considering a European multicountry setting, we can assess the importance of country-level corporate governance on government ownership. We expect that any positive benefit of government ownership during a crisis will be lower in countries where the risk of government expropriation is high, that is, with greater corruption and poorer investor protection.

Our analysis is based on a unique sample of 4,737 listed firms in 28 European countries for which we collected ownership information in each year during the 20052009 period. We use different empirical approaches to test our hypotheses. First, we estimate OLS regressions to investigate the determinants of stock returns during the crisis period for all firms in our sample and differentiate between firms with and without government ownership. A potential problem with this approach is that any observed relation between government ownership and stock returns during the crisis might result from a systematic relation between government ownership and other firm characteristics. For example, if the government retains ownership in firms generating more cash, then these firms may have done relatively well in the crisis because of 
their characteristics and not because of government ownership as such. We therefore rely on a propensity score matching technique to construct a restricted sample in which each firm with government ownership is matched to firms without government ownership, based on a number of firm characteristics prior to the crisis. Third, we estimate panel regressions in which we model the market-to-book ratio as a function of government ownership at the end of 2006, distinguishing between the crisis years and pre-crisis years. This approach allows us to consider a longer time period and to control for firm fixed effects.

Our results suggest that firms with government block ownership at the beginning of the crisis experienced a smaller reduction in stock price over the crisis period compared to firms without government ownership. However, this effect is only observed for firms located in countries with low corruption and good investor protection. We also find that, overall, government ownership tended to be negatively related to the market-to-book ratio. However, the market-to-book ratio of firms with pre-crisis government ownership increased significantly in 2008 and 2009 compared to those without government ownership, ceteris paribus. Again, this relation is driven by firms in countries with low corruption and good investor protection. All findings are confirmed by a number of robustness checks.

Our study contributes to the literature in a number of ways. First, while Borisova and Megginson (2011) and Borisova et al. (2012b) find that government ownership helped to stabilize a firm's cost of debt financing in 2008-2010, we are- to the best of our knowledge - the first to investigate the relation between government ownership and firm value during a crisis. Our results suggest that the costs of government ownership 
decrease during a crisis. Second, we add to the literature on country-level institutional quality by providing evidence that the positive relation between government ownership and firm value during a crisis particularly occurs in an institutional environment where the risk of investor expropriation by governments is small.

The remainder of our study is organized as follows. In the following section, we provide a brief literature review and develop our hypotheses. Then, we describe the sample and variables used in the paper and provide descriptive statistics. Next, we present the empirical evidence. The final section concludes the paper.

\section{Hypotheses}

There are several channels through which a financial crisis can affect the value of government ownership. The benefits of government ownership might increase during a crisis because implicit and explicit government guarantees become more valuable when firms face a higher likelihood of failing, which is the case in economic crisis periods (Ivashina and Scharfstein, 2010; Puri et al., 2011; Santos, 2011). Furthermore, a crisis period may induce governments to temporarily forgo the short-term political incentives of diverting firm resources, since such actions may result in more bankrupt firms and eliminate the ability to expropriate firm assets in the future (Friedman et al., 2003).

On the other hand, the likelihood of expropriation by the government at the expense of the other shareholders could also increase during the crisis, since the incentive for controlling shareholders to expropriate tends to go up as the expected return on 
investment falls (Johnson et al., 2000). Furthermore, it could be argued that government-owned firms will do especially poorly during a crisis because their welldocumented inefficiencies make it harder for them to react appropriately to the crisis. While the results of prior work lead us to expect that government ownership is negatively related to firm value in non-crisis periods, the net effect of the crisis on the benefits and costs of government ownership is not clear a priori. We hypothesize that firms with government ownership experienced a smaller reduction in value during the crisis than firms without government ownership, especially because implicit and explicit government guarantees reduced external financing constraints for government owned firms (Almeida et al., 2011; Duchin et al., 2010).

H1: Firms with government ownership experienced a smaller reduction in firm value during the global financial crisis compared to firms without government ownership.

The effect of government ownership on firm value during a crisis is likely to depend on the quality of the institutional environment in which the firm operates. Weak institutions and poor investor protection make it easier for any controlling shareholder to expropriate firm value. It is also well documented that the quality of the institutional environment influences government expropriation-related incentives (Borisova et al., 2012a; Boubakri et al., 2005b; La Porta et al., 1998; Shleifer, 1998). In countries with weaker institutions, government ownership is more likely to be motivated by politicians' agendas than by social objectives (Shleifer, 1998). Borisova et al. (2012a) show that government ownership is negatively related to the governance quality of firms in civil law countries but positively related to governance in common law countries. 
Moreover, a financial crisis makes protection of investors from potential expropriation even more pivotal (Johnson et al., 2000; Rajan and Zingales, 1998). Falling expected returns on investment increase the incentives for expropriation by controlling shareholders and managers and a crisis may force investors to realize that their investments are not adequately protected. However, high-quality institutions and strong investor protection may help to reduce such political distortions because these grant investors more power to protect their rights, making it also more difficult for governments to intervene in firm operations and decision making and ultimately reduce the risk of expropriation by local governments. Likewise, in countries with a poor institutional environment, that is, countries with high corruption and poor investor protection, government ownership is more likely to be driven by the personal and political objectives of politicians than by value-maximizing objectives. In summary, the predicted positive effect of government ownership during the crisis may be mitigated by a high expropriation risk in poor institutional quality countries. Therefore, we expect any positive effect of government ownership during the crisis to be weaker in countries with high corruption and poor investor protection.

H2: The positive relation between government ownership and firm value during the global financial crisis was less pronounced in countries with higher corruption and poorer investor protection. 


\section{Data, variables, and propensity score matching}

\subsection{Data}

We gather time-series ownership data from 2004-2009 for all listed companies included in the yearly tapes (December issues) of the Amadeus ownership database of Bureau van Dijk. Amadeus provides financial statement and ownership data for European private and public companies and is compiled from several well-established national information collectors. Since the Amadeus ownership database uses different sets of shareholder categories before and after 2004 and some of our variables are based on lagged values, we use a sample starting in 2005 to avoid any potential bias due to differences in shareholder classification. For each company that we observed at least once during 2005-2009, we identified all recorded shareholders for each year during the observation period. Amadeus reports the total ownership and direct ownership of each shareholder. Total ownership is based on both direct and indirect shareholdings, that is, via other firms. For this study, we use data on total ownership. When total ownership is missing but direct ownership data are available, direct ownership is used. ${ }^{3}$ On the basis of ownership categories reported in Amadeus, we then identified the state and public authority categories as government shareholders. In addition, shareholders whose name contained such words as ministry, state of government, treasury, and council were also identified as government shareholders.

\footnotetext{
${ }^{3}$ Results are unaffected when we use total ownership data only, which reduces the sample size by about $20 \%$.
} 
For companies with more than one government shareholder in one year, we used the sum of these shareholders' total ownership as the government ownership for that year. Next, we selected all firms with accounting information in the Amadeus financial database and merged the resulting dataset with stock price information from TF Datastream (Reuters) available for the years considered. In a subsequent selection step, we restricted our sample to observations with data available to calculate the main control variables. This yields a sample of 28,971 firm-year observations pertaining to 7,388 individual firms. Requiring lagged values for government ownership further reduces the total number of observations to 19,331 for 5,070 unique firms. To estimate standard errors clustered by firm and country, we further require two consecutive year observations for each firm. The final sample for the panel data regressions includes 18,854 observations for 4,737 unique firms. ${ }^{4}$ It is important to note that this sample selection process does not suffer from survivorship bias because if a firm delists or goes bankrupt in a specific year, the firm-year observations we identified that are prior to the year of delisting or bankruptcy remain in the sample.

\subsection{Government ownership and institutional quality}

We use two different measures of government ownership. The dummy variable GovDummy captures government presence and takes the value of one if the firm has government ownership over 5\% and zero otherwise. The continuous variable GovPercentage measures the level of government ownership and is the proportion of state-owned shares (identified as described before) to total shares. We eliminate

\footnotetext{
${ }^{4}$ The results are very similar when we use the sample of 19,331 observations and do not take into account two-way clustered standard errors.
} 
government ownership below $5 \%$, because in some countries in our sample, such as France or Belgium, listed firms are not obliged to report ownership below $5 \%$. Furthermore, government ownership at very small levels is more likely to reflect passive holdings by sovereign wealth funds, which are unrelated to our hypotheses.

Institutional quality is measured in two ways. First, we use the yearly control of the corruption index from the World Bank, which measures "the extent to which public power is exercised for private gain, including both petty and grand forms of corruption, as well as 'capture' of the state by elites and private interests" (Kaufmann et al., 2010, p. 4). The index ranges between -2.5 and 2.5 , with higher values corresponding to better governance outcomes. ${ }^{5} \mathrm{We}$ measure investor protection in a country by the anti-director rights index of La Porta et al. (1998), updated by Martynova and Renneboog (2010) for the year 2005. As an alternative measure of investor protection, we also used the corrected anti-director rights index (2005 values) of Spamann (2010). The results for the Spamann index (available from the authors upon request) are very similar to those for the anti-director rights index reported in the paper, but they are based on a smaller number of observations, because the Spamann index is not available for 15 countries in our sample.

Insert Table 1 about here

\footnotetext{
${ }^{5}$ As an alternative measure, we also used the rule of law score from the same source, which measures the extent to which agents have confidence in and abide by the rules of society and, in particular, the quality of contract enforcement, the police, and the courts, as well as the likelihood of crime and violence. The results (available from the authors upon request) are very similar to those reported in the paper on the control of corruption.
} 
Table 1 provides information on the country distribution of observations. The sample includes firms from 28 countries. Three countries together represent more than $50 \%$ of all the observations: the United Kingdom (32.26\%), Germany (13.66\%), and France $(13.01 \%)$. A total of 809 observations have block government shareholdings over 5\%. The largest number (120) is in the United Kingdom, followed by Poland (95) and Sweden and Germany (94). For the overall sample, the mean percentage of government ownership of firms with government blockholdings is $21.73 \%$, and tends to be high in Eastern European countries such as Lithuania (85.14\%), the Czech Republic (68.21\%), Croatia (55.24\%), and Slovenia (51.00\%). The control of corruption measure of 2009 is negative for Russia only, implying that all other countries in our sample in 2009 had a score above the worldwide mean of zero. With respect to the anti-director rights index, values range between zero (Luxembourg) and four (Austria, Croatia, France, Italy, Slovenia and Spain).

Insert Table 2 about here

Table 2 reports the year-by-year distribution of government ownership in our sample. During the period of study, governments held shares in $4.29 \%$ of all observations in the sample. The noticeable increase in the proportion of observations with government ownership in 2007 and 2008 illustrates the significant government intervention during the financial crisis years. Interestingly, government ownership quickly returns to pre-crisis levels in 2009. The interval breakdown of the sample further shows that the increases in firms with government ownership stakes during 
2007-2008 are mainly attributable to observations with relatively small government stakes (i.e., below 20\%). This suggests that governments mainly took significant yet minority equity stakes in listed firms during the financial crisis and nationalized only a small fraction of private firms (117 out of 18,854 , or $0.61 \%$ of the sample).

\subsection{Firm performance and other firm characteristics}

We use two firm performance measures. The first is Crisis Return, the cumulative buy-and-hold stock return over the crisis period from July 16, 2007, to March 9, 2009, when the Stoxx Europe 600 Index declined from a peak of 399.71 to a trough of 157.97. To investigate the value of government ownership in the full period 20052009, we measure firm value by the market-to-book ratio. This ratio is calculated as the sum of the market value of equity and the book value of debt, divided by the book value of assets, where the market value of equity is the market capitalization at yearend. To reduce the impact of outliers, we take the natural logarithm to generate our dependent variable LnMarket/Book.

To measure systematic risk during the crisis period, Beta is computed by regressing a firm's monthly stock returns in the pre-crisis period on the Datastream Total Market Index, using Dimson's (1979) method. We also consider LnAssets, which is the natural $\log$ of total assets (in thousands of euros) to measure firm size. The variable Leverage is the ratio of total liabilities to total assets and FixedAssets is the ratio of fixed assets over total assets. Finally, we consider three ownership variables to take into account the presence of other block shareholders: Corporate $B H$ is the percentage of block shareholdings over $5 \%$ of non-financial companies, Family $\mathrm{BH}$ is the 
percentage of block shareholdings over $5 \%$ of family or individual owners, and Institutional $\mathrm{BH}$ is the percentage of block shareholdings over $5 \%$ of banks, mutual funds, insurance, private equity, or financial companies. All continuous variables except for LnMarket/Book, LnAssets, and GovPercentage are winsorized at the first and 99th percentiles to mitigate the impact of outliers; corporate, family, and institutional blockholdings are winsorized at the 95 th percentile. ${ }^{6}$

Insert Table 3 about here

Table 3 provides summary statistics for the firm characteristics. All statistics are based on the full sample of 18,854 observations for the period 2005-2009, except for Crisis Return and Beta, which are based on 3,433 firm observations for the crisis period only. Not surprisingly, stock returns during the crisis tended to be very negative: The average crisis return from July 2007 to March 2009 was $-58.7 \%$, while the median was $-64.1 \%$

\footnotetext{
${ }^{6}$ As noted by Bureau van Dijk, the Amadeus ownership database might contain some unidentified overlaps between total ownership and direct ownership. In those cases, total ownership might exceed $100 \%$. Suppose, for example, that firm A directly owns $100 \%$ of firm B, which directly owns $100 \%$ of firm C. If an information source also indicates that firm A holds total ownership (100\%) of firm C, then the total ownership percentage in the database will be $200 \%$. As a robustness check, we re-estimated all regressions in this paper with ownership based on (a) direct shareholdings and (b) dummy variables equal to one if the firm has corporate, family, or institutional blockholdings, but this does not affect our findings for government ownership.
} 


\subsection{Propensity score matching}

To take into account that government ownership might be correlated with other firm characteristics, we use propensity score (PS) matching to select matching firms for each observation with government ownership. As documented by Heckman and Navarro-Lozano (2004) and Smith and Todd (2005), only variables that simultaneously influence the participation decision and the outcome variable should be included in estimating the propensity score. Based on finance theory and previous empirical evidence, we include firm characteristics that have been previously identified as affecting government ownership. The following logit model is used to estimate the propensity score for a firm with government ownership:

$$
\begin{aligned}
\text { GovDummy }_{i t}= & a+b_{1} \text { Leverage }_{i t}+b_{2} \text { ROA }_{i t}+b_{3} \text { FixedAssets }_{i t}+b_{4} \text { LnAsset }_{i t} \\
& +b_{5} \text { LnMarket }_{\text {Book }}+b_{6} \text { CashFlow }_{i t}+b_{7}\left(\text { BH }_{i t}\right) \\
& +b_{8}(\text { Year Dummies })+e_{i t}
\end{aligned}
$$

All variables are defined as before, except $R O A$, which is net income over total assets. We first exclude observations with a missing value for the variables in the propensity score estimation model to get a "clean" sample that is necessary to run the Stata suite for PS matching. After this step, the "clean" sample consists of 17,331 observations without government ownership and 799 with government ownership. We eliminate government-owned firms for which we cannot find a sufficient number of comparable non-government-owned firms, because the estimate of the effect of government ownership would be noisy over this subset due to the limited number of data points 
observed. Following Heckman et al. (1997) and Smith and Todd (2005), we impose a common support constraint by dropping treatment observations whose propensity score is higher than the maximum or less than the minimum propensity score of the controls. For each government-owned firm with the common support, we then apply the $k$-nearest neighbors matching method and identify five matching firms with the most similar propensity scores. Our final matched sample consists of 568 treated firm-year observations with government ownership and 2,043 control firm-year observations without government ownership.

Insert Table 4 about here

Table 4 reports the mean values for firm-year observations without and with government ownership for the full sample and for the one-to-five matched sample. All reported means are for the firm-year observations in 2005-2009, except for Crisis Return and Beta. In the full sample, there are a number of significant differences between firms with and without government ownership. Firms with government ownership have a significantly lower market to book, have a less negative crisis return, have higher systematic risk and are larger, have a higher ratio of fixed assets to total assets, a higher ROA, and they generate more cash flow. ${ }^{7}$ They are also more likely

\footnotetext{
${ }^{7}$ An explanation for our finding that firms with government ownership have a slightly higher but statistically significant beta than those without government ownership might be that government
} 
to have institutional blockholders and less likely to have corporate and/or family blockholders. In the one-to-five matched sample, firms with government ownership only differ from firms without government ownership with respect to crisis return and size. $^{8}$

\section{Results}

\subsection{Government ownership and stock returns during the crisis}

Following a large body of research that uses cumulative stock returns during a crisis as a measure of the change in value during a financial crisis (e.g., Lemmon and Lins, 2003; Lins et al., 2013; Mitton, 2002), we first consider cumulative stock returns during the global financial crisis. We estimate the following cross-sectional OLS model to test the relation between government ownership and cumulative buy-andhold returns during the crisis period:

ownership is more prevalent in risky industries, where the benefits of government ownership are higher. Firms with government ownership may also be more likely to undertake risky investments because of lower budget constraints, easier access to credit, and government rescue in case of distress (Boubakri et al., 2013b). On the other hand, it could be argued that a government's aversion to risk may lead firms with government ownership to pursue conservative investments (Boubakri et al., 2013a). Furthermore, resource dependency theory suggests that firms with government ownership may have lower risk because their connections to politicians allow them to better cope with external uncertainties. However, our finding suggests that firms with government ownership tend to have higher systematic risk.

${ }^{8}$ The size difference disappears in a one-to-one matched sample. Unreported regressions for the oneto-one matched sample confirm those for the one-to-five matched sample. However, we chose not to report these results because the sample size becomes very small. 
Crisis Return $=a+b_{1}$ GovOwn $+b_{2}$ (Firm Characteristics $)+b_{3}(B H)$

$+b_{4}($ Industry Dummies $)+b_{5}($ Country Dummies $)+e$

Government ownership (GovOwn) is measured by GovDummy and GovPercentage. Firm characteristics that are plausibly related to differences in risk across firms are Beta, LnAssets, Leverage, and Market/Book (Lemmon and Lins, 2003; Lins et al., 2013; Mitton, 2002). The measure $B H$ includes corporate, family, and institutional blockholdings. The independent variables are measured at the end of 2006, that is, before the start of the crisis, to avoid any spurious correlation between these variables and stock returns during the crisis.

Insert Table 5 about here

The regression results are reported in Table 5. Regressions 1 to 3 are based on the full sample and regressions 4 to 6 are based on the one-to-five matched sample. While propensity score matching reduces the likelihood that any effect of government ownership we might observe is driven by firm characteristics correlated with government ownership, it has the disadvantage that it strongly reduces the size of the sample. ${ }^{9}$ In the first regression, which is based on the full sample, the GovDummy coefficient is 0.102 and significant at the $1 \%$ level, indicating that the stock returns of firms with a government blockholding were $10.2 \%$ higher than those of other firms, all else being equal. Consistent with other studies on crisis returns, we also find that

${ }^{9}$ Rubin (1997) points out that propensity score methods work better in larger samples than in small samples. The distributional balance of observed covariates created by subclassification using an estimated propensity score is an expected balance and, in a small sample, there may be substantial imbalances of some covariates (Rubin, 1997). 
Beta is negatively related to stock returns in all the regressions: During a financial crisis, high-risk firms tend to perform worse. We also find that shareholdings by corporate owners are positively correlated with stock returns during the crisis period. This result is consistent with the argument that firms belonging to a business group benefit from the internal capital market during a crisis (Almeida and Kim, 2013). The positive effect of government ownership holds when we consider the percentage level of government ownership in regression 2. The coefficient of GovPercentage is 0.253 and significant at the $1 \%$ level (regression 2), indicating that an increase of $1 \%$ in government ownership is associated with an increase of 25 percentage points in the crisis period return. Given the possibility that the influence of government shareholdings on corporate value is non-monotonic (e.g., Borisova and Megginson, 2011; Tian and Estrin, 2008), we include the squared term of GovPercentage in regression 3, but the coefficient is not significant, indicating that there is no nonmonotonic relation between government ownership and stock returns. In regressions 4 and 5, which are based on the one-to-five matched sample, the government ownership coefficients are again positive but not statistically significant. Consequently, the statistically significant effect of government ownership observed in regressions 1 to 3 might be driven by intrinsic differences between firms with government ownership and firms without government ownership. However, our analysis so far does not take into account that the value of government ownership during a crisis might depend on institutional quality (H2). This is investigated in the next section. 


\subsection{Country institutional quality and the value of government ownership}

We consider three subsamples based on the control of corruption indicator of the World Bank and three subsamples based on the anti-director rights index of La Porta et al. (1998), updated by Martynova and Renneboog (2010) for 2005. We split the sample based on the tertiles of the control of corruption score. Observations for countries whose control of corruption is in the lower (upper) tertile are classified into the low (high) institutional quality subsample; observations for countries whose control of corruption value is in the middle tertile are classified into the middle subsample. The low subsample includes Croatia, the Czech Republic, Greece, Italy, Latvia, Lithuania, Poland, Russia, and Slovakia. The middle subsample includes Belgium, Estonia, France, Hungary, Ireland, Portugal, Slovenia, and Spain. The high subsample includes Austria, Denmark, Finland, Germany, Iceland, Luxembourg, the Netherlands, Norway, Sweden, Switzerland, and the United Kingdom. As for the antidirector rights index, low investor protection countries are those with a score of zero or one, while high investor protection countries have a score of three or four. Countries with a score of two are in the middle subgroup (see Table 1).

Insert Table 6 about here

Table 6 reports the results on the relation between the percentage of government ownership at the end of 2006 and stock returns for the full sample, considering control of corruption (regressions 1 and 3) and investor protection (regressions 4 and 6), and 
for the one-to-five matched sample, considering control of corruption (regressions 7 to 9$).{ }^{10,11}$ When we use all observations, the GovPercentage coefficients are positive and significant in the subsamples with middle or high control of corruption and in the subsample with high anti-director rights index. Interestingly, we find a significantly negative coefficient for the low anti-director rights subsample, suggesting that the costs of government ownership actually increased during the crisis in countries with low investor protection. For the one-to-five matched sample, we also find that government ownership was associated with a significantly lower reduction in stock value during the crisis, but not in countries with a low control of corruption. Combined, these results support our second hypothesis, that the positive effect of government ownership on firm value during the crisis occurs only in countries with good institutional quality, suggesting that investors value government ownership more during a crisis in countries where there is a low risk of government expropriation.

Insert Table 7 about here

The event window we use to determine crisis returns is almost 20 months long, from July 16, 2007, to March 9, 2009. This raises the possibility that changes in firm characteristics in this period affected stock returns. To minimize the risk that our

\footnotetext{
${ }^{10}$ In the remainder of the paper, we report the results for regressions in which government ownership is measured by the percentage of government ownership to save space. However, the results are very similar if we use a government ownership dummy.

${ }^{11}$ Note that we do not use the anti-director rights index here because the number of observations in the low category is too low to reliably interpret regression results. We also do not include country dummies here because the number of degrees of freedom would be too low.
} 
results are caused by changing characteristics of government-owned firms versus other firms, we narrow the period over which we measure crisis performance. Following Lins et al. (2013), we consider seven-month stock returns starting in the middle of August 2008. The results, which are reported in Table 7, confirm our previous findings. Government ownership is associated with significant higher stock returns from August 2008 to March 2009 and this effect is driven by firms located in countries with a medium/high control of corruption and a high anti-director rights index.

\subsection{Government ownership and the market-to-book ratio}

So far we have used stock returns to measure firm performance during the crisis. In an alternative approach, we consider the relation between government ownership and the market-to-book ratio and estimate the following fixed effects model for the full sample for 2005-2009:

$$
\begin{aligned}
\text { LnMarket/Book }_{i t}= & a+b_{1} \text { GovPercentage }_{i t-1} \\
& +b_{2} \text { GovPercentage06 } *(\text { Crisis Year Dummies }) \\
& +b_{3}\left(\text { Firm Characteristics }_{i t}\right)+b_{4}\left(\text { BH }_{i t-1}\right) \\
& +b_{5}\left(\text { BHO6 }_{i}\right) *(\text { Crisis Year Dummies })+b_{6}(\text { Year Dummies })+e_{i t}
\end{aligned}
$$

This approach allows us to make use of the full dataset and consider the value of government ownership before and during the crisis years 2007 to 2009. In this model, GovPercentage $_{i t-1}$ represents the percentage of government ownership of firm $i$ in year $t$ - 1. The term Crisis Year Dummies is a vector of dummies indicating the years 2007 
to 2009. It could be argued that government ownership and performance are determined simultaneously: If a company performs poorly, the government might take an equity stake or increase its equity stake to support the company. ${ }^{12} \mathrm{We}$ therefore consider the effect of pre-crisis government ownership (i.e., in 2006) on firm value during the crisis years 2007 to 2009 to avoid potential changes in government stakes in response to firm value changes during the crisis. It is very unlikely that the government ownership before the crisis will reflect the effect of the crisis. To ascertain that the effect of government ownership at the start of the crisis is not a proxy for other blockholder effects, we add our blockholding measures for each year, as well as the interaction between $\mathrm{BHOC}_{i}$, that is, institutional, family, and industrial blockholdings at the start of the crisis, with Crisis Year Dummies. We also include the firm-specific characteristics LnAssets, Leverage, and FixedAssets. Large firms may realize scale economies and have better access to bank credits, which could improve corporate profitability and consequently firm valuation as well (e.g., Dewenter and Malatesta, 2001; Maury, 2006). Following Lemmon and Lins (2003) and Sun and Tong (2003), we include Leverage to control for any possible leverage effect (e.g., Kang and Stulz, 1996; McConnell and Servaes, 1995). We also include FixedAssets to capture a firm's growth opportunities (e.g., Morck et al., 1988; Tian and Estrin, 2007). Since Himmelberg et al. (1999) show that unobserved heterogeneity across firms can generate a spurious correlation between ownership and performance, we use panel data regressions with firm fixed effects. A Hausman test indicates that the firm fixed

\footnotetext{
${ }^{12}$ Within the European Union, state aid measures can only be implemented after approval by the European Commission. The commission also has the power to recover incompatible state aid (see http://ec.europa.eu/competition/state_aid/overview/).
} 
effect model is the most appropriate. Standard errors are heteroskedasticity consistent and clustered by firm and country.

Insert Table 8 about here

Table 8 reports the regression results. The findings for the blockholding variables are not reported here to save space, but they are available from the authors upon request. The coefficients of the interaction variables GovPercentage06*2008 and GovPercentage06*2009, which measure the relation between government ownership before the crisis and firm value during the crisis, are all positive and significant at the $5 \%$ level or better, except for the low control of corruption and anti-director rights subsample, where it is mostly insignificant. These results again confirm that government ownership led to a smaller decline in firm value during the crisis years and that the effect is most pronounced in high control of corruption and anti-director rights institutional settings. ${ }^{13}$

The lagged percentage government ownership coefficient is negative but not statistically significant in regression 1 . We find a negative and significant relation (at

\footnotetext{
${ }^{13}$ Since the control of corruption indicator changes over time, some countries are in different subsamples in different years. For the panel regressions, the low subsample includes the Czech Republic (2006-2009), Croatia, Greece, Hungary (2009), Italy, Latvia, Lithuania, Poland, Russia, Slovakia (2006-2009). The middle subsample includes Belgium, the Czech Republic (2005), Estonia, Hungary (2005-2008), Ireland (2005-2009), Luxembourg (2005), Portugal, Slovakia (2005), Slovenia, Spain, Germany (2007-2009), France, and the United Kingdom (2007-2009). The high subsample includes Austria, Denmark, Finland, Germany (2005-2006), Iceland, Ireland (2008), Luxembourg (2006-2009), the Netherlands, Norway, Sweden, Switzerland, and the United Kingdom (2005-2006).
} 
the $1 \%$ level) between government ownership and firm value in the low control of corruption subsample (regression 2), indicating a negative relation between government ownership and firm value in countries with low control of corruption. However, it should be taken into account that this finding might be affected by endogeneity. A change in firm value might induce governments to change their stake in the company or firm value and government ownership might both be affected by changing firm characteristics.

\subsection{Additional analyses}

We conducted a number of additional analyses to test the robustness of the results. ${ }^{14}$ First, if it is the commitment of governments to support firms that is driving our results, we expect a weaker effect for those firms the government was selling off. It could be argued that a reduction in government ownership prior to the crisis suggests that the government was less willing to support the firm during the crisis. We investigate whether the effect of government ownership is different for 37 firms in which government ownership was reduced in the years before the crisis (up to 2006). We measure this effect by including in the stock return regressions the interaction between government ownership and a dummy that equals one if government ownership was reduced in 2005 or 2006. Consistent with this argument, we find a negative coefficient for the interaction variable, but the effect is not statistically significant.

${ }^{14}$ All results are available from the authors upon request. 
Second, to further ascertain that the positive effect of government ownership during the crisis is not driven by firms bailed out by the government, in the crisis return regressions we add a dummy equal to one if the government obtained a blockholder stake in the firm in 2007,2008 , or 2009 . We find that equity investments by the government during the crisis were negatively related to stock returns during the crisis (albeit not statistically significant). This confirms common wisdom that governments take up equity stakes in poorly performing firms during a crisis. It also suggests that the positive crisis effect of government ownership that we find is not caused by government bailouts during the crisis.

Third, since financial firms have different capital structures and generally receive higher levels of government support compared to non-financial firms in case of distress, we exclude firms in financial industries (Standard Industrial Classification codes 6000-6999) to avoid possible confounding effects. The results for this subsample confirm our prior results.

Fourth, the effect of government ownership might be different for domestic firms and foreign firms (Borisova et al., 2012b). Governments are more likely to support domestic firms because the default of a foreign firm in which they have a stake is less likely to carry the political stigma associated with the failure of a domestic firm. Governments are also less likely to impose social and political goals on foreign firms. It could also be argued that local government investors are better at overcoming information asymmetries. On the other hand, foreign governments might be better monitors of firms in which they invest. However, the number of observations with foreign government ownership stakes in our sample is very limited. As a robustness 
check, we re-estimated the main regressions distinguishing between domestic and foreign government ownership. The results for domestic government ownership confirm those reported in the paper, while we do not find any significant effects for foreign government ownership.

Fifth, our measure of government ownership is based on total ownership, which takes into account both direct and indirect shareholdings, that is, via other firms. To check whether indirect shareholdings make a difference, we re-estimated the main regressions using direct ownership instead of total ownership. The results again confirm our main results

Finally, a large part of the firms in our sample are located in the United Kingdom. To check whether this affects our results, we re-estimated our regressions without UK firms. Again, the results confirm the findings reported in the paper.

\section{Conclusions}

This study examines the value of government ownership in Europe during the global financial crisis. Using a large sample of European listed firms during 2005-2009, our results suggest that the benefits of government ownership increased relative to the costs of government ownership during the crisis. Firms with government ownership experienced a smaller decrease in stock value than other firms did. Furthermore, our results suggest that the positive effect of government ownership occurs only in countries with good investor protection and low corruption. This indicates that a 
sufficient level of institutional quality is necessary for the benefits of government ownership to materialize.

Overall, our findings suggest that, in countries with good investor protection and low corruption, the positive effect of implicit and explicit government guarantees helps to alleviate financial supply shocks. Our research provides guidance in the ongoing debate about the proper role of governments in public firms. It is often argued that the political objectives of government as owners cause inefficiencies, but our findings highlight the value of government guarantees for firms during a crisis. Furthermore, we shed light on the importance of institutional quality in the functioning of government ownership.

Our study is subject to some limitations that point to some interesting avenues for further research. First, while our results suggest that the benefits of government ownership increase during a crisis, this does not imply that the economy as a whole benefits. If government support of firms is beneficial to the shareholders of these firms, this may come at the expense of other participants in the economy. For example, governments might support incumbent old-economy firms at the expense of new firms and new industries (Rajan and Zingales, 2003). So an interesting avenue for further research could be to examine how supported firms perform in the long run and what happens if the governments step out. Second, our dataset does not allow us to directly examine how government ownership affects firm value. It is not clear to 
what extent our results are determined by implicit and/or explicit government guarantees that reduce financing constraints during a crisis and/or by the reduced incentives of governments to divert resources from these firms. An investigation of the direct mechanisms in which government ownership improves firm value would therefore also be an interesting avenue for further research. For example, it would be interesting to learn more about how government ownership affects the financing and corporate governance of firms during a crisis.

Third, our sample consists of European firms, which allows us to consider the impact of the institutional environment in which firms operate. However, most of the firms in our sample are located in countries with relatively strong institutions, where investors are well protected. This raises the question of what the value of government ownership during a crisis is in countries with very weak institutions. Furthermore, our results are based on the global financial crisis. So, we cannot be sure that our findings apply to other crises. It would therefore be interesting to investigate the effect of government ownership for a worldwide sample that considers different crises. Finally, another route that future research might take is to study differences in direct government ownership versus participation via sovereign wealth funds (a distinction that we cannot observe). 


\section{References}

Agrawal, A., Knoeber, C. R. 2001. Do some outside directors play a political role? Journal of Law and Economics 44(1), 179-198.

Almeida, H., Kim, C., 2013. Internal capital markets in business groups: Evidence from the Asian financial crisis. Working paper, College of Business at Illinois.

Almeida, H., Laranjeira, B., Campello, M., Weisbenner, S. 2011. Corporate debt maturity and the real effects of the 2007 credit crisis. Critical Finance Review 1(1), 3-58.

Bae, K.-H., Baek, J.-S., Kang, J.-K., Liu, W.-L. 2012. Do controlling shareholders’ expropriation incentives imply a link between corporate governance and firm value? Theory and evidence. Journal of Financial Economics 105, 412-435.

Baek, J. S., Kang, J. K., Park, K. S. 2004. Corporate governance and firm value: Evidence from the Korean financial crisis. Journal of Financial Economics 71, $265-313$.

Bennedsen, M. 2000. Political ownership. Journal of Public Economics 76, 559-581.

Boardman, A. E., Vining, A. R. 1989. Ownership and performance in competitive environments, a comparison of the performance of private, mixed, and stateowned enterprises. Journal of Law and Economics 32(1), 1-33.

Borisova, G., Brockman, P., Salas, J. M., Zagorchev, A. 2012a. Government ownership and corporate governance: Evidence from the EU. Journal of Banking and Finance 36(11), 2917-2934. 
Borisova, G., Fotak, V., Holland, K., Megginson, W. L. 2012b. Government ownership and the cost of debt: Evidence from government investments in publicly traded firms. Working paper, University of Oklahoma.

Borisova, G., Megginson, W. L. 2011. Does government ownership affect the cost of debt? Evidence from privatization. Review of Financial Studies 24(8), 26932737.

Boubakri, N., Cosset, J. 1998. The financial and operating performance of newly privatized firms: Evidence from developing countries. Journal of Finance 53(3), 1081-1110.

Boubakri, N., Cosset, J., Guedhami, O. 2005a. Liberalization, corporate governance and the performance of privatized firms in developing countries. Journal of Corporate Finance 11(5), 767-790.

Boubakri, N., Cosset, J. C., Guedhami, O. 2005b. Postprivatization corporate governance: The role of ownership structure and protection. Journal of Financial Economics 76, 369-399.

Boubakri, N., Cosset, J. C., Saffar, W. 2012. The impact of political connections on firms' operating performance and financing decisions. Journal of Financial Research 35(3), 397-423.

Boubakri, N., Cosset, J. C., Saffar, W. 2013a. The role of state and foreign owners in corporate risk-taking: Evidence from privatisation. Journal of Financial Economics 108, 641-658. 
Boubakri, N., Mansi, S. A., Saffar, W. 2013b. Political connections, connectedness, and corporate risk taking. Journal of International Business Studies 44, 195215.

Boycko, M., Shleifer, A., Vishny, R. W. 1996. A theory of privatisation. Economic Journal 106(435), 309-319.

Brandt, L., Li, H. 2003. Bank discrimination in transition economies, ideology, information, or incentives? Journal of Comparative Economics 31(3), 387413.

Charumilind, C., Kali, R., Wiwattanakantang, Y. 2006. Connected lending: Thailand before the financial crisis. Journal of Business 79(1), 181-218.

Dewenter, K. L., Malatesta, P. H. 2001. State-owned and privately owned firms: An empirical analysis of profitability, leverage, and labor intensity. American Economic Review 91(1), 320-334.

Dimson, E. 1979. Risk measurement when shares are subject to infrequent trading. Journal of Financial Economics 7(2), 197-226.

D’Souza, J., Megginson, W., Nash, R. 2005. Effect of institutional and firm-specific characteristics on post-privatization performance: Evidence from developed countries. Journal of Corporate Finance 11, 747-766.

Duchin, R., Ozbas, O., Sensoy, B. A. 2010. Costly external finance, corporate investment, and the subprime mortgage credit crisis. Journal of Financial Economics 97(3), 418-435. 
Faccio, M. 2006. Politically connected firms. American Economic Review 96(1), $369-386$.

Faccio, M., Marchica, M., Mura, R. 2011. Large shareholder diversification and corporate risk-taking. Review of Financial Studies 24(11), 3601-3641.

Faccio, M., Masulis, R. W., McConnell, J. J. 2006. Political connections and corporate bailouts. Journal of Finance 61(6), 2597-2635.

Fan, J. P. H., Rui, O. M., Zhao, M. 2008. Public governance and corporate finance: Evidence from corruption cases. Journal of Comparative Economics 36(3), 343-364.

Friedman, E., Johnson, S, Mitton, T. 2003. Propping and tunneling. Journal of Comparative Economics 31, 732-750.

Gupta, N. 2005. Partial privatization and firm performance. Journal of Finance 60(2), 987-1015.

Heckman, J., Ichimura, H., Todd, P. E. 1997. Matching as an econometric evaluation estimator: Evidence from evaluating a job training programme, Review of Economic Studies 64, 605-654.

Heckman, J., Navarro-Lozano, S. 2004. Using matching, instrumental variables, and control functions to estimate economic choice models. Review of Economics and Statistics 86, 30-57

Hillman, A. J., Wither, M. C., Collins, B. J. 2009. Resource dependency theory: A review. Journal of Management 35(6), 1404-1427. 
Himmelberg, C. P., Hubbard, R. G., Palia, D. 1999. Understanding the determinants of managerial ownership and the link between ownership and performance. Journal of Financial Economics 53(3), 353-384.

Ivashina, V., Scharfstein, D. 2010. Bank lending during the financial crisis of 2008. Journal of Financial Economics 97(3), 319-338.

John, K, Litov, L., Yeung, B. 2008. Corporate governance and risk taking. Journal of Finance 58(4), 1679-1728.

Johnson, S., Boone, P., Breach, A., Friedman, E. 2000. Corporate governance in the Asian financial crisis. Journal of Financial Economics 58(1-2), 141-186.

Kang, J. K., Stulz, R. M. 1996. How different is Japanese corporate finance? An investigation of the information content of new security issues. Review of Financial Studies 9(1), 109-139.

Kaufmann, D., Kraay, A., Mastruzzi, M. 2010. The worldwide governance indicators: Methodology and analytical issues. World Bank, Washington, DC.

Khwaja, A. I., Mian, A. 2005. Do lenders favor politically connected firms? Rent provision in an emerging financial market. Quarterly Journal of Economics 120(4), 1371-1411.

Kole, S. R., Mulherin, J. H. 1997. The government as shareholder: A case from the United States. Journal of Law and Economics 40, 1-22.

Laffont, J. J., Tirole, J. 1991. Privatization and incentives. Journal of Law, Economics and Organization 7(Special Issue), 84-105. 
La Porta, R., Lopez-de-Silanes, F., Shleifer, A., Vishny, R. W. 1998. Law and finance. Journal of Political Economy 106(6), 1113-1155.

Lemmon, M. L., Lins, K. V. 2003. Ownership structure, corporate governance, and firm value: Evidence from the East Asian financial crisis. Journal of Finance 58(4), 1445-1468.

Lins, K. V., Volpin, P. F., Wagner, H. F. 2013. Does family control matter? International evidence from the 2008-2009 financial crisis. Review of Financial Studies 26(10), 2583-2619.

Martynova, M., Renneboog, L. 2010. A corporate governance index: Convergence and diversity of national corporate governance regulations. Working paper, Tilburg University.

Maury, B. 2006. Family ownership and firm performance: Empirical evidence from Western European corporations. Journal of Corporate Finance 12(2), 321-341.

McConnell, J. J., Servaes, H. 1995. Equity ownership and the two faces of debt. Journal of Financial Economics 39(1), 131-157.

Megginson, W. L., Nash, R. C., Van Randenborgh, M. 1994. The financial and operating performance of newly privatized firms: An international empirical analysis. Journal of Finance 49(2), 403-452.

Megginson, W. L., Netter, J. M. 2001. From state to market: A survey of empirical studies on privatization. Journal of Economic Literature 39(2): 321-389.

Mitton, T. 2002. A cross-firm analysis of the impact of corporate governance on the East Asian financial crisis. Journal of Financial Economics 64(2), 215-241. 
Morck, R., Shleifer, A., Vishny, R. W. 1988. Management ownership and market valuation: An empirical analysis. Journal of Financial Economics 20, 293315.

Nanto, D. 2009. The global financial crisis: Foreign and trade policy effects, Congressional Research Service 7-5700 (R40496), accessible via: http://www.fas.org/sgp/crs/misc/R40496.pdf.

Pfeffer, J., Salancik, G. R. 1978. The External Control of Organizations: A Resource Dependency Perspective. Harper \& Row, New York.

Puri, M., Rocholl, J., Steffen, S. 2011. Global retail lending in the aftermath of the US financial crisis: Distinguishing between supply and demand effects. Journal of Financial Economics 100(3), 556-578.

Rajan, R. G., Zingales, L. 1998. Which capitalism? Lessons from the East Asian crisis. Journal of Applied Economics 11(3), 40-48.

Rajan, R. G., Zingales, L. 2003. The great reversals: The politics of financial development in the 20th century. Journal of Financial Economics 69, 5-50.

Rubin, D. B. 1997. Estimating causal effects from large data sets using propensity scores. Annals of Internal Medicine 127(8S), 757-763.

Santos, J. A. C. 2011. Bank corporate loan pricing following the subprime crisis. Review of Financial Studies 24(6), 1916-1943.

Sapienza, P. 2004. The effects of government ownership on bank lending. Journal of Financial Economics 72(2), 357-384. 
Schmidt, K. M. 1996. The costs and benefits of privatization: An incomplete contracts approach. Journal of Law, Economics and Organization 12(1), 1-24.

Shleifer, A. 1998. State versus private ownership. Journal of Economic Perspectives 12(4), 133-150.

Shleifer, A., Vishny, R. W. 1994. Politicians and firms. Quarterly Journal of Economics 109(4), 995-1025.

Shleifer, A., Vishny, R.W. 1998. The Grabbing Hand: Government Pathologies and Their Cures. Harvard University Press, Cambridge, MA.

Smith, A.J., Todd, E.P. 2005. Does matching overcome LaLonde's critique of nonexperimental estimators? Journal of Econometrics 125, 305-353.

Spamann, H. 2010. The "Antidirector Rights Index" revisited. Review of Financial Studies 23(2), 467-486.

Sun, Q., Tong, W. H. S. 2003. China share issue privatization: The extent of its success. Journal of Financial Economics 70, 183-222.

The Economist. 2012. The visible hand. January 12.

Tian, L., Estrin, S. 2008. Retained state shareholding in Chinese PLCs: Does government ownership always reduce corporate value? Journal of Comparative Economics 36(1), 74-89.

Vickers, J., Yarrow, G. 1991. Economic perspectives on privatization. Journal of Economic Perspectives 5(2), 111-132. 


\section{Table 1}

Country distribution of the sample. This table reports the country distribution of the sample and the measures of institutional quality for each country. The control of corruption measure is from the Worldwide Governance Indicators of Kaufmann et al. (2010). The Anti-Director Rights Index is that of La Porta et al. (1998), updated for 2005 by Martynova and Renneboog (2010).

\begin{tabular}{|c|c|c|c|c|c|c|}
\hline Country & $\begin{array}{l}\text { No. of } \\
\text { firms }\end{array}$ & $\begin{array}{l}\text { No. of } \\
\text { obs. }\end{array}$ & $\begin{array}{c}\text { No of obs. } \\
\text { with block } \\
\text { GovOwn }\end{array}$ & $\begin{array}{c}\text { Mean of } \\
\text { block } \\
\text { GovOwn } \\
(\%)\end{array}$ & $\begin{array}{c}\text { Control of } \\
\text { corruption } \\
\text { (2009) }\end{array}$ & $\begin{array}{c}\text { Anti- } \\
\text { Director } \\
\text { Rights } \\
\text { Index }\end{array}$ \\
\hline Austria & 57 & 192 & 9 & 33.48 & 1.758 & 4 \\
\hline Belgium & 129 & 513 & 8 & 35.75 & 1.371 & 2 \\
\hline Croatia & 25 & 101 & 3 & 55.24 & 0.216 & 4 \\
\hline \multicolumn{7}{|l|}{ Czech } \\
\hline Republic & 7 & 25 & 2 & 68.21 & 0.963 & 3 \\
\hline Denmark & 115 & 404 & 67 & 10.18 & 1.872 & 2 \\
\hline Estonia & 7 & 32 & 4 & 25.68 & 1.130 & 2 \\
\hline Finland & 116 & 516 & 43 & 32.07 & 1.937 & 2 \\
\hline France & 567 & 2,452 & 66 & 26.40 & 1.425 & 4 \\
\hline Germany & 641 & 2,576 & 94 & 26.87 & 1.634 & 3 \\
\hline Greece & 193 & 878 & 15 & 37.92 & 0.638 & 3 \\
\hline Hungary & 8 & 34 & 0 & - & 0.817 & 2 \\
\hline Iceland & 7 & 19 & 0 & - & 1.717 & 2 \\
\hline Italy & 179 & 716 & 51 & 34.02 & 0.388 & 4 \\
\hline Latvia & 14 & 53 & 1 & 38.62 & 0.833 & 2 \\
\hline Lithuania & 32 & 107 & 10 & 85.14 & 0.724 & 3 \\
\hline Luxembourg & 7 & 22 & 3 & 29.23 & 1.831 & 0 \\
\hline Netherlands & 85 & 355 & 10 & 10.06 & 1.781 & 1 \\
\hline Norway & 131 & 448 & 76 & 24.04 & 1.878 & 3 \\
\hline Poland & 169 & 675 & 95 & 18.91 & 0.683 & 2 \\
\hline Portugal & 47 & 200 & 2 & 5.71 & 1.037 & 3 \\
\hline Romania & 3 & 12 & 0 & - & 0.101 & 2 \\
\hline Russia & 14 & 40 & 6 & 33.55 & -0.773 & - \\
\hline Slovakia & 2 & 6 & 0 & - & 0.654 & 2 \\
\hline Slovenia & 19 & 65 & 1 & 51.00 & 1.113 & 4 \\
\hline Spain & 135 & 559 & 6 & 17.43 & 1.133 & 4 \\
\hline Sweden & 265 & 1,086 & 94 & 11.57 & 1.927 & 2 \\
\hline $\begin{array}{l}\text { Switzerland } \\
\text { United }\end{array}$ & 156 & 686 & 23 & 25.36 & 1.751 & 1 \\
\hline Kingdom & 1,607 & 6,082 & 120 & 10.12 & 1.706 & 3 \\
\hline Total & 4,737 & 18,854 & 809 & 21.73 & & \\
\hline
\end{tabular}




\section{Table 2}

Year distribution of the sample. This table reports the number of observations in each year and the distribution of observations with government ownership in each year.

\begin{tabular}{|c|c|c|c|c|c|c|c|}
\hline \multirow[b]{2}{*}{ Year } & \multirow{2}{*}{$\begin{array}{c}\text { Total } \\
\text { observations } \\
\text { (1) }\end{array}$} & \multicolumn{6}{|c|}{ Observations with block government ownership } \\
\hline & & $\begin{array}{r}\text { Total } \\
(2)\end{array}$ & $\begin{array}{c}\% \\
(2) /(1)\end{array}$ & $5-10 \%$ & $10-20 \%$ & $20-50 \%$ & $>50 \%$ \\
\hline 2005 & 2,548 & 65 & 2.55 & 15 & 14 & 23 & 13 \\
\hline 2006 & 4,004 & 111 & 2.77 & 34 & 20 & 32 & 25 \\
\hline 2007 & 4,507 & 251 & 5.57 & 129 & 60 & 36 & 26 \\
\hline 2008 & 3,909 & 285 & 7.29 & 146 & 71 & 41 & 27 \\
\hline 2009 & 3,886 & 97 & 2.50 & 24 & 20 & 27 & 26 \\
\hline Total & 18,854 & 809 & 4.29 & 348 & 185 & 159 & 117 \\
\hline
\end{tabular}




\section{Table 3}

Descriptive statistics based on 18,854 firm-year observations for 2005-2009, except for Crisis Return and Beta, which are based on the crisis period sample (3,433 firms). The variable Crisis Return is the cumulative stock return from July 16, 2007, to March 9, 2009 and Beta is computed by regressing a firm's monthly stock return in the pre-crisis period on the corresponding country index return from Datastream using Dimson's (1979) method. The term LnMarket/Book is the natural logarithm of the market-to-book ratio of total assets; Leverage is the ratio of total liabilities to total assets; LnAssets is the natural logarithm of total assets; FixedAssets is the ratio of fixed assets to total assets; Corporate $B H$ is the percentage of blockholdings of non-financial companies; Family $B H$ is the percentage of blockholdings of families; and Institutional $B H$ is the percentage of blockholdings of banks, mutual funds, insurance, private equity, and financial companies.

\begin{tabular}{lcccccc}
\hline Variables & $\mathrm{N}$ & Mean & Median & St. dev. & Minimum & Maximum \\
\hline Crisis Return & 3,433 & -0.587 & -0.641 & 0.275 & -0.974 & 0.389 \\
LnMarket/Book & 18,854 & 0.268 & 0.173 & 0.602 & -3.848 & 7.978 \\
Beta & 3,433 & 0.823 & 0.706 & 1.239 & -36.576 & 10.554 \\
Leverage & 18,854 & 0.520 & 0.536 & 0.275 & 0.002 & 1.854 \\
LnAssets & 18,854 & 11.909 & 11.739 & 2.233 & 0.000 & 21.483 \\
FixedAssets & 18,854 & 0.517 & 0.508 & 0.258 & 0.000 & 0.990 \\
Corporate BH & 18,854 & 0.238 & 0.110 & 0.284 & 0.000 & 0.886 \\
Family BH & 18,854 & 0.152 & 0.000 & 0.221 & 0.000 & 0.702 \\
Institutional BH & 18,854 & 0.342 & 0.254 & 0.322 & 0.000 & 0.998 \\
\hline
\end{tabular}




\section{Table 4}

Firms without government ownership versus firms without government ownership. This table reports the mean values for firms without and with government ownership and a $t$-test of the difference for the full sample and the one-to-five matched sample. All variables are defined as before, except for $R O A$ which is net income over total assets. The term n.s. denotes not significant; * denotes $p<0.10$; ** denotes $p<0.05$; ** denotes $p<0.01$.

\begin{tabular}{lcccccc}
\hline \multicolumn{1}{c}{$\begin{array}{c}\text { Government } \\
\text { ownership: }\end{array}$} & No & Yes & Difference & No & Yes & Difference \\
\hline InMarket/Book & 0.271 & 0.203 & $-* * *$ & 0.264 & 0.266 & n.s. \\
Crisis Return & -0.589 & -0.528 & $+* *$ & -0.610 & -0.497 & $+* * *$ \\
Beta & 0.822 & 0.846 & $+* *$ & 0.736 & 0.746 & n.s. \\
LnAssets & 11.830 & 13.672 & $+* * *$ & 13.677 & 14.190 & $+* * *$ \\
Leverage & 0.520 & 0.518 & n.s. & 0.575 & 0.588 & n.s. \\
FixedAssets & 0.512 & 0.608 & $+* * *$ & 0.558 & 0.576 & n.s. \\
ROA (\%) & 0.458 & 3.576 & $+* * *$ & 2.863 & 3.329 & n.s. \\
CashFlow & 0.034 & 0.074 & $+* * *$ & 0.0705 & 0.078 & n.s. \\
Corporate BH & 0.240 & 0.184 & $-* * *$ & 0.212 & 0.194 & n.s. \\
Family BH & 0.156 & 0.057 & $-* * *$ & 0.058 & 0.049 & n.s. \\
Institutional BH & 0.339 & 0.413 & $+* * *$ & 0.400 & 0.403 & n.s. \\
\hline
\end{tabular}




\section{Table 5}

Government ownership and crisis returns. This table reports the OLS regression results in which the dependent variable is Crisis Return. GovOwn is measured by a dummy equal to 1 for firms with government ownership at the end of 2006 and zero otherwise (columns 1 and 4) and the percentage of government ownership at the end of 2006 (columns 2, 3, 5, and 6), GovPercentage ${ }^{2}$, is the squared term of GovPercentage at the end of 2006. All the other variables are defined as before. The $t$-statistics (in parentheses) are based on heteroscedasticity-consistent standard errors clustered by firm and country. ${ }^{*}$ denotes $p<$ 0.10 ; ** denotes $p<0.05$; *** denotes $p<0.01$.

\begin{tabular}{|c|c|c|c|c|c|c|}
\hline \multirow{3}{*}{$\begin{array}{l}\text { Sample: } \\
\text { GovOwn: }\end{array}$} & (1) & (2) & (3) & (4) & $(5)$ & (6) \\
\hline & \multicolumn{3}{|c|}{ Full sample } & \multicolumn{3}{|c|}{ 1-to-5 matched sample } \\
\hline & \multirow{2}{*}{$\begin{array}{c}\text { GovDummy } \\
\begin{array}{c}0.102^{* * *} \\
(3.370)\end{array}\end{array}$} & \multicolumn{2}{|c|}{ GovPercentage } & \multirow{2}{*}{$\begin{array}{c}\text { GovDummy } \\
0.060 \\
(1.291)\end{array}$} & \multicolumn{2}{|c|}{ GovPercentage } \\
\hline GovOwn & & $\begin{array}{c}0.253^{* * *} \\
(2.772)\end{array}$ & $\begin{array}{l}0.436^{* *} \\
(2.302)\end{array}$ & & $\begin{array}{c}0.189 \\
(1.503)\end{array}$ & $\begin{array}{c}-0.039 \\
(-0.171)\end{array}$ \\
\hline GovPercentage ${ }^{2}$ & & & $\begin{array}{c}-0.298 \\
(-1.164)\end{array}$ & & & $\begin{array}{c}0.358 \\
(0.945)\end{array}$ \\
\hline Beta & $\begin{array}{c}-0.050^{* * *} \\
(-6.722)\end{array}$ & $\begin{array}{c}-0.050^{* * *} \\
(-6.726)\end{array}$ & $\begin{array}{c}-0.050^{\text {*** }} \\
(-6.739)\end{array}$ & $\begin{array}{c}-0.089^{* * *} \\
(-7.074)\end{array}$ & $\begin{array}{c}-0.089^{\text {*** }} \\
(-6.967)\end{array}$ & $\begin{array}{c}-0.088^{* * *} \\
(-6.948)\end{array}$ \\
\hline LnMarket/Book & $\begin{array}{c}0.000 \\
(0.055)\end{array}$ & $\begin{array}{c}0.000 \\
(0.069)\end{array}$ & $\begin{array}{c}0.000 \\
(0.061)\end{array}$ & $\begin{array}{l}0.044^{* *} \\
(2.347)\end{array}$ & $\begin{array}{l}0.046^{* *} \\
(2.539)\end{array}$ & $\begin{array}{l}0.046^{* *} \\
(2.508)\end{array}$ \\
\hline Leverage & $\begin{array}{c}-0.033 \\
(-1.330)\end{array}$ & $\begin{array}{c}-0.034 \\
(-1.416)\end{array}$ & $\begin{array}{c}-0.034 \\
(-1.403)\end{array}$ & $\begin{array}{c}-0.037 \\
(-0.966)\end{array}$ & $\begin{array}{c}-0.042 \\
(-1.138)\end{array}$ & $\begin{array}{c}-0.045 \\
(-1.253)\end{array}$ \\
\hline LnAssets & $\begin{array}{l}-0.014^{* *} \\
(-2.068)\end{array}$ & $\begin{array}{l}-0.014^{* *} \\
(-2.093)\end{array}$ & $\begin{array}{l}-0.014^{* *} \\
(-2.097)\end{array}$ & $\begin{array}{c}0.014 \\
(1.369)\end{array}$ & $\begin{array}{c}0.014 \\
(1.480)\end{array}$ & $\begin{array}{c}0.015 \\
(1.593)\end{array}$ \\
\hline Corporate $B H$ & $\begin{array}{l}0.057^{* * *} \\
(2.273)\end{array}$ & $\begin{array}{l}0.058^{* *} \\
(2.264)\end{array}$ & $\begin{array}{l}0.058^{* *} \\
(2.256)\end{array}$ & $\begin{array}{l}0.094^{* *} \\
(1.999)\end{array}$ & $\begin{array}{l}0.112^{* *} \\
(2.113)\end{array}$ & $\begin{array}{l}0.117^{* *} \\
(2.085)\end{array}$ \\
\hline Family $B H$ & $\begin{array}{c}0.006 \\
(0.331)\end{array}$ & $\begin{array}{c}0.007 \\
(0.335)\end{array}$ & $\begin{array}{c}0.007 \\
(0.370)\end{array}$ & $\begin{array}{c}-0.104^{* * *} \\
(-2.972)\end{array}$ & $\begin{array}{c}-0.093^{* * *} \\
(-3.607)\end{array}$ & $\begin{array}{c}-0.098^{* * *} \\
(-3.426)\end{array}$ \\
\hline Institutional BH & $\begin{array}{c}-0.008 \\
(-0.336)\end{array}$ & $\begin{array}{c}-0.005 \\
(-0.215)\end{array}$ & $\begin{array}{c}-0.005 \\
(-0.208)\end{array}$ & $\begin{array}{c}-0.172^{* * *} \\
(-4.172)\end{array}$ & $\begin{array}{l}-0.152^{* *} \\
(-3.181)\end{array}$ & $\begin{array}{c}-0.152^{* * *} \\
(-3.305)\end{array}$ \\
\hline Constant & $\begin{array}{l}-0.323^{* * *} \\
(-3.152)\end{array}$ & $\begin{array}{c}-0.328^{* * *} \\
(-3.227)\end{array}$ & $\begin{array}{l}-0.326^{\text {**** }} \\
(-3.202)\end{array}$ & $\begin{array}{l}-0.572^{* * *} \\
(-3.938)\end{array}$ & $\begin{array}{l}-0.589^{* * *} \\
(-4.400)\end{array}$ & $\begin{array}{l}-0.596 \\
(-4.561)\end{array}$ \\
\hline Industry FE & Yes & Yes & Yes & Yes & Yes & Yes \\
\hline Country FE & Yes & Yes & Yes & Yes & Yes & Yes \\
\hline $\begin{array}{l}N \\
R^{2}\end{array}$ & $\begin{array}{l}3,433 \\
0.170\end{array}$ & $\begin{array}{l}3,433 \\
0.170\end{array}$ & $\begin{array}{l}3,433 \\
0.170\end{array}$ & $\begin{array}{c}381 \\
0.174\end{array}$ & $\begin{array}{c}381 \\
0.179\end{array}$ & $\begin{array}{c}381 \\
0.182\end{array}$ \\
\hline
\end{tabular}




\section{Table 6}

Government ownership, crisis return, and institutional quality. This table reports the OLS regression results in which the dependent variable is Crisis Return. All the variables are defined as before. The $t$-statistics (in parentheses) are based on heteroscedasticity-consistent standard errors clustered by firm and country. $*$ denotes $p<0.10$; ** denotes $p<0.05$; *** denotes $p<0.01$.

\begin{tabular}{|c|c|c|c|c|c|c|c|c|c|}
\hline \multirow{4}{*}{$\begin{array}{l}\text { Sample: } \\
\text { Indicator: } \\
\text { Institutional quality: }\end{array}$} & (1) & (2) & (3) & (4) & (5) & (6) & (7) & (8) & (9) \\
\hline & \multirow{2}{*}{\multicolumn{3}{|c|}{$\begin{array}{c}\text { Full sample } \\
\text { Control of corruption }\end{array}$}} & \multirow{2}{*}{\multicolumn{3}{|c|}{$\begin{array}{c}\text { Full sample } \\
\text { Anti-Director Rights Index }\end{array}$}} & \multirow{2}{*}{\multicolumn{3}{|c|}{$\begin{array}{l}\text { 1-to5 Matched sample } \\
\text { Control of corruption }\end{array}$}} \\
\hline & & & & & & & & & \\
\hline & Low & Middle & High & Low & Middle & High & Low & Middle & High \\
\hline GovPercentage & $\begin{array}{c}0.034 \\
(0.542)\end{array}$ & $\begin{array}{l}0.440^{* * *} \\
(8.130)\end{array}$ & $\begin{array}{l}0.299^{* *} \\
(2.068)\end{array}$ & $\begin{array}{c}-0.690^{* * *} \\
(-5.082)\end{array}$ & $\begin{array}{c}0.161 \\
(1.079)\end{array}$ & $\begin{array}{c}0.312^{* * *} \\
(3.412)\end{array}$ & $\begin{array}{c}0.151 \\
(0.778)\end{array}$ & $\begin{array}{c}0.171^{*} \\
(1.837)\end{array}$ & $\begin{array}{l}0.313^{* *} \\
(2.113)\end{array}$ \\
\hline Beta & $\begin{array}{c}-0.059^{* * * *} \\
(-7.018)\end{array}$ & $\begin{array}{l}-0.071^{* * *} \\
(-10.898)\end{array}$ & $\begin{array}{l}-0.040^{* * *} \\
(-6.936)\end{array}$ & $\begin{array}{c}-0.103^{* * *} \\
(-3.602)\end{array}$ & $\begin{array}{l}-0.050^{* * * *} \\
(-2.766)\end{array}$ & $\begin{array}{c}-0.047^{* * *} \\
(-5.689)\end{array}$ & $\begin{array}{l}-0.038 \\
(-0.796)\end{array}$ & $\begin{array}{l}-0.065^{* * *} \\
(-3.825)\end{array}$ & $\begin{array}{c}-0.093^{* * *} \\
(-5.955)\end{array}$ \\
\hline LnMarket/Book & $\begin{array}{c}0.001 \\
(0.151)\end{array}$ & $\begin{array}{l}-0.017^{* * * *} \\
(-7.934)\end{array}$ & $\begin{array}{c}0.002 \\
(1.023)\end{array}$ & $\begin{array}{c}-0.021^{* * *} \\
(-4.226)\end{array}$ & $\begin{array}{c}-0.001 \\
(-0.138)\end{array}$ & $\begin{array}{c}0.004 \\
(1.343)\end{array}$ & $\begin{array}{c}0.071^{* * * *} \\
(2.814)\end{array}$ & $\begin{array}{l}0.086^{* * *} \\
(18.714)\end{array}$ & $\begin{array}{l}0.038^{*} \\
(1.686)\end{array}$ \\
\hline Leverage & $\begin{array}{l}-0.132^{* * * *} \\
(-3.567)\end{array}$ & $\begin{array}{l}-0.100^{* * * *} \\
(-4.345)\end{array}$ & $\begin{array}{c}-0.006 \\
(-0.399)\end{array}$ & $\begin{array}{c}0.035 \\
(0.196)\end{array}$ & $\begin{array}{l}-0.133^{* * *} \\
(-5.103)\end{array}$ & $\begin{array}{c}-0.030 \\
(-1.230)\end{array}$ & $\begin{array}{l}-0.323^{* * *} \\
(-2.652)\end{array}$ & $\begin{array}{c}-0.029 \\
(-0.452)\end{array}$ & $\begin{array}{c}0.021 \\
(0.542)\end{array}$ \\
\hline LnAssets & $\begin{array}{c}0.001 \\
(0.437)\end{array}$ & $\begin{array}{l}-0.029^{* * *} \\
(-13.743)\end{array}$ & $\begin{array}{c}-0.010 \\
(-1.183)\end{array}$ & $\begin{array}{c}-0.005^{* * *} \\
(-3.139)\end{array}$ & $\begin{array}{l}-0.022^{* * *} \\
(-3.265)\end{array}$ & $\begin{array}{c}-0.012 \\
(-1.439)\end{array}$ & $\begin{array}{c}0.058^{* * *} \\
(4.675)\end{array}$ & $\begin{array}{c}0.007 \\
(0.796)\end{array}$ & $\begin{array}{c}0.013 \\
(1.060)\end{array}$ \\
\hline Corporate BH & $\begin{array}{c}0.018 \\
(0.855)\end{array}$ & $\begin{array}{l}0.063^{*} \\
(1.820)\end{array}$ & $\begin{array}{l}0.067^{*} \\
(1.877)\end{array}$ & $\begin{array}{c}-0.002 \\
(-0.077)\end{array}$ & $\begin{array}{c}0.081^{* * *} \\
(2.788)\end{array}$ & $\begin{array}{l}0.060^{* *} \\
(2.016)\end{array}$ & $\begin{array}{l}0.122^{*} \\
(1.768)\end{array}$ & $\begin{array}{l}0.137^{*} \\
(1.756)\end{array}$ & $\begin{array}{c}0.112 \\
(1.644)\end{array}$ \\
\hline Family BH & $\begin{array}{c}-0.028 \\
(-0.986)\end{array}$ & $\begin{array}{l}-0.047 \\
(-0.963)\end{array}$ & $\begin{array}{c}0.040 \\
(1.399)\end{array}$ & $\begin{array}{c}0.215^{* * *} \\
(5.879)\end{array}$ & $\begin{array}{c}0.021 \\
(0.696)\end{array}$ & $\begin{array}{c}-0.002 \\
(-0.175)\end{array}$ & $\begin{array}{c}0.083 \\
(1.386)\end{array}$ & $\begin{array}{c}-0.037 \\
(-0.533)\end{array}$ & $\begin{array}{c}-0.108 \\
(-1.440)\end{array}$ \\
\hline Institutional BH & $\begin{array}{c}0.045 \\
(0.599)\end{array}$ & $\begin{array}{c}0.026 \\
(0.731)\end{array}$ & $\begin{array}{c}-0.024 \\
(-1.006)\end{array}$ & $\begin{array}{c}0.004 \\
(0.059)\end{array}$ & $\begin{array}{c}0.068 \\
(1.408)\end{array}$ & $\begin{array}{c}-0.024 \\
(-1.109)\end{array}$ & $\begin{array}{c}0.062 \\
(0.954)\end{array}$ & $\begin{array}{l}-0.114^{*} \\
(-1.889)\end{array}$ & $\begin{array}{c}-0.183^{* * *} \\
(-3.271)\end{array}$ \\
\hline Constant & $0.333^{* * *}$ & $0.136^{* * *}$ & $-0.281^{* * *}$ & $-0.444^{* * *}$ & $0.670^{* * *}$ & $-0.372^{* * *}$ & $-1.218^{* * *}$ & $-0.865^{* * *}$ & $-0.563^{* * *}$ \\
\hline
\end{tabular}




\begin{tabular}{lccccccccc} 
& $(4.336)$ & $(6.834)$ & $(-3.995)$ & $(-5.785)$ & $(6.651)$ & $(-3.298)$ & $(-6.044)$ & $(-7.535)$ & $(-3.193)$ \\
Industry FE & Yes & Yes & Yes & Yes & Yes & Yes & Yes & Yes & Yes \\
Country FE & Yes & Yes & Yes & Yes & Yes & Yes & No & No & No \\
$N$ & 473 & 698 & 2,262 & 206 & 624 & 2,468 & 36 & 93 & 252 \\
$R^{2}$ & 0.285 & 0.168 & 0.144 & 0.234 & 0.284 & 0.152 & 0.649 & 0.265 & 0.189 \\
\hline
\end{tabular}




\section{Table 7}

The alternative event window August 2008-March 2009. This table reports the OLS regression results in which the dependent variable is the buy-and-hold return from August 2008 to March 2009. All variables are defined as before. The $t$ statistics (in parentheses) are based on heteroscedasticity-consistent standard errors clustered by firm and country. * denotes $p<0.10 ; * *$ denotes $p<0.05 ; * * *$ denotes $p<0.01$.

\begin{tabular}{|c|c|c|c|c|c|c|c|c|c|}
\hline \multirow{4}{*}{$\begin{array}{l}\text { Sample: } \\
\text { Indicator: } \\
\text { Institutional quality: }\end{array}$} & \multirow{2}{*}{\multicolumn{3}{|c|}{$\begin{array}{c}(2) \\
\text { Full sample }\end{array}$}} & (4) & (5) & (6) & (7) & (8) & (9) \\
\hline & & & & \multirow{2}{*}{\multicolumn{3}{|c|}{$\begin{array}{c}\text { Full sample } \\
\text { Anti-Director Rights Index }\end{array}$}} & \multirow{2}{*}{\multicolumn{3}{|c|}{$\begin{array}{l}\text { 1-to5 matched sample } \\
\text { Control of corruption }\end{array}$}} \\
\hline & \multicolumn{3}{|c|}{ Control of corruption } & & & & & & \\
\hline & Low & Middle & High & Low & Middle & High & Low & Middle & High \\
\hline GovPercentage & $\begin{array}{l}-0.077 \\
(-1.287)\end{array}$ & $\begin{array}{l}0.279^{* * * *} \\
(4.235)\end{array}$ & $\begin{array}{l}0.231^{* *} \\
(2.239)\end{array}$ & $\begin{array}{c}-0.168 \\
(-1.083)\end{array}$ & $\begin{array}{l}-0.013 \\
(-0.173)\end{array}$ & $\begin{array}{c}0.209^{* * *} \\
(2.714)\end{array}$ & $\begin{array}{l}-0.117 \\
(-0.746)\end{array}$ & $\begin{array}{c}0.136 \\
(1.087)\end{array}$ & $\begin{array}{l}0.244^{* *} \\
(2.165)\end{array}$ \\
\hline Beta & $\begin{array}{l}-0.036^{* * *} \\
(-9.540)\end{array}$ & $\begin{array}{l}-0.065^{* * *} \\
(-37.904)\end{array}$ & $\begin{array}{l}-0.039^{* * *} \\
(-6.526)\end{array}$ & $\begin{array}{l}-0.085^{* *} \\
(-2.288)\end{array}$ & $\begin{array}{l}-0.036^{* *} \\
(-2.181)\end{array}$ & $\begin{array}{l}-0.043^{* * *} \\
(-7.146)\end{array}$ & $\begin{array}{c}-0.041 \\
(-1.318)\end{array}$ & $\begin{array}{l}-0.059^{* *} \\
(-3.197)\end{array}$ & $\begin{array}{c}-0.095^{* * *} \\
(-5.893)\end{array}$ \\
\hline LnMarket/Book & $\begin{array}{l}-0.007 \\
(-1.000)\end{array}$ & $\begin{array}{l}-0.008^{* * * *} \\
(-6.119)\end{array}$ & $\begin{array}{c}0.006^{* * * *} \\
(2.579)\end{array}$ & $\begin{array}{l}-0.016^{* * *} \\
(-7.909)\end{array}$ & $\begin{array}{l}-0.003 \\
(-0.478)\end{array}$ & $\begin{array}{c}0.007^{* * * *} \\
(2.834)\end{array}$ & $\begin{array}{l}0.069^{* * *} \\
(2.958)\end{array}$ & $\begin{array}{l}0.037^{* * * *} \\
(4.981)\end{array}$ & $\begin{array}{c}0.049^{* * * *} \\
(5.076)\end{array}$ \\
\hline Leverage & $\begin{array}{l}-0.123^{* *} \\
(-2.101)\end{array}$ & $\begin{array}{l}-0.066^{* *} \\
(-2.332)\end{array}$ & $\begin{array}{c}-0.017 \\
(-0.754)\end{array}$ & $\begin{array}{c}0.024 \\
(0.173)\end{array}$ & $\begin{array}{l}-0.149^{* * * *} \\
(-4.544)\end{array}$ & $\begin{array}{c}-0.022 \\
(-1.055)\end{array}$ & $\begin{array}{l}-0.168^{*} \\
(-2.127)\end{array}$ & $\begin{array}{l}-0.076 \\
(-0.858)\end{array}$ & $\begin{array}{c}0.001 \\
(0.025)\end{array}$ \\
\hline LnAssets & $\begin{array}{l}-0.004^{*} \\
(-1.761)\end{array}$ & $\begin{array}{l}-0.033^{* * *} \\
(-27.711)\end{array}$ & $\begin{array}{l}-0.013^{* * *} \\
(-2.769)\end{array}$ & $\begin{array}{l}-0.010^{* * *} \\
(-16.627)\end{array}$ & $\begin{array}{l}-0.014 \\
(-1.330)\end{array}$ & $\begin{array}{l}-0.017^{* * *} \\
(-3.263)\end{array}$ & $\begin{array}{l}0.048^{* * * *} \\
(11.140)\end{array}$ & $\begin{array}{l}0.008 \\
(0.900)\end{array}$ & $\begin{array}{c}0.007 \\
(0.728)\end{array}$ \\
\hline Corporate BH & $\begin{array}{c}0.009 \\
(0.329)\end{array}$ & $\begin{array}{c}0.017 \\
(0.695)\end{array}$ & $\begin{array}{c}0.045 \\
(1.615)\end{array}$ & $\begin{array}{c}0.033 \\
(0.811)\end{array}$ & $\begin{array}{c}0.034 \\
(1.058)\end{array}$ & $\begin{array}{l}0.037^{*} \\
(1.812)\end{array}$ & $\begin{array}{l}0.087^{+} \\
(1.695)\end{array}$ & $\begin{array}{c}0.125 \\
(1.386)\end{array}$ & $\begin{array}{c}0.117 \\
(1.437)\end{array}$ \\
\hline Family BH & $\begin{array}{c}-0.040 \\
(-1.017)\end{array}$ & $\begin{array}{c}-0.027 \\
(-0.936)\end{array}$ & $\begin{array}{l}0.043^{*} \\
(1.701)\end{array}$ & $\begin{array}{l}0.229^{* * *} \\
(11.074)\end{array}$ & $\begin{array}{c}0.034 \\
(0.752)\end{array}$ & $\begin{array}{c}-0.002 \\
(-0.115)\end{array}$ & $\begin{array}{c}0.030 \\
(0.551)\end{array}$ & $\begin{array}{c}-0.143^{* * *} \\
(-4.004)\end{array}$ & $\begin{array}{l}0.154^{* *} \\
(2.110)\end{array}$ \\
\hline Institutional BH & $\begin{array}{c}-0.044 \\
(-0.787)\end{array}$ & $\begin{array}{c}-0.001 \\
(-0.021)\end{array}$ & $\begin{array}{l}-0.029^{*} \\
(-1.739)\end{array}$ & $\begin{array}{c}0.019 \\
(0.343)\end{array}$ & $\begin{array}{c}0.035 \\
(0.506)\end{array}$ & $\begin{array}{c}-0.035^{* * *} \\
(-2.765)\end{array}$ & $\begin{array}{c}0.101 \\
(1.606)\end{array}$ & $\begin{array}{l}-0.018 \\
(-0.352)\end{array}$ & $\begin{array}{c}-0.152^{* * *} \\
(-2.664)\end{array}$ \\
\hline Constant & $-0.133^{* * *}$ & $0.078^{* * *}$ & $0.221^{* *}$ & $-0.301^{* * *}$ & 0.127 & -0.077 & $-1.090^{* * * *}$ & $-0.635^{* * *}$ & $-0.388^{* * * *}$ \\
\hline
\end{tabular}




\begin{tabular}{lccccccccc} 
& $(-2.866)$ & $(3.446)$ & $(2.326)$ & $(-11.924)$ & $(1.162)$ & $(-0.387)$ & $(-14.834)$ & $(-5.585)$ & $(-2.889)$ \\
Industry FE & Yes & Yes & Yes & Yes & Yes & Yes & Yes & Yes & Yes \\
Country FE & Yes & Yes & Yes & Yes & Yes & Yes & No & No & No \\
$N$ & 473 & 698 & 2,262 & 206 & 624 & 2,468 & 36 & 93 & 252 \\
$R^{2}$ & 0.182 & 0.178 & 0.098 & 0.187 & 0.163 & 0.111 & 0.608 & 0.232 & 0.225 \\
\hline
\end{tabular}




\section{Table 8}

Government ownership and LnMarket/Book. This table reports the fixed effects regression results in which the dependent variable is LnMarket/Book for the full sample and for subgroups based on the lagged control of corruption score (columns 2-4) and the AntiDirector Rights Index in 2005 (columns 5-7) in 2005. All the variables are defined as before, except GovPercentage_lag, which is the lagged percentage of government ownership. Additionally, all regressions include lagged Corporate BH, Family BH, and Institutional BH, as well as Corporate BH, Family BH, and Institutional BH at the end of 2006, interacted with the 2007, 2008, and 2009 year dummies. The $t$-statistics (in parentheses) are based on heteroscedasticity-consistent standard errors clustered by firm and country. * denotes $p<0.10$; $* *$ denotes $p<0.05 ; * * *$ denotes $p<0.01$.

\begin{tabular}{|c|c|c|c|c|c|c|c|}
\hline \multirow{3}{*}{$\begin{array}{l}\text { Indicator: } \\
\text { Sample: }\end{array}$} & \multirow{3}{*}{$\begin{array}{l}\text { (1) } \\
\text { Full }\end{array}$} & (2) & & (4) & (5) & (6) & (7) \\
\hline & & \multicolumn{3}{|c|}{ Control of corruption } & \multicolumn{3}{|c|}{ Anti-Director Rights Index } \\
\hline & & Low & Middle & High & Low & Middle & High \\
\hline $\begin{array}{l}\text { GovPercentage06 } \\
* 2009\end{array}$ & $\begin{array}{l}0.276^{* * *} \\
(3.874)\end{array}$ & $\begin{array}{l}0.163^{*} \\
(1.866)\end{array}$ & $\begin{array}{c}0.311^{* * * *} \\
(3.960)\end{array}$ & $\begin{array}{c}0.225^{* * * *} \\
(4.014)\end{array}$ & $\begin{array}{c}0.087 \\
(0.319)\end{array}$ & $\begin{array}{l}0.385^{* *} \\
(2.202)\end{array}$ & $\begin{array}{l}0.260^{* * *} \\
(3.518)\end{array}$ \\
\hline $\begin{array}{l}\text { GovPercentage06 } \\
* 2008\end{array}$ & $\begin{array}{l}0.366^{* * *} \\
(3.961)\end{array}$ & $\begin{array}{c}0.102 \\
(0.992)\end{array}$ & $\begin{array}{c}0.469^{* * *} \\
(3.756)\end{array}$ & $\begin{array}{l}0.282^{* *} \\
(2.109)\end{array}$ & $\begin{array}{c}0.236 \\
(0.283)\end{array}$ & $\begin{array}{c}0.343^{* * *} \\
(2.629)\end{array}$ & $\begin{array}{l}0.421^{\text {**** }} \\
(3.879)\end{array}$ \\
\hline $\begin{array}{l}\text { GovPercentage06 } \\
\text { *2007 }\end{array}$ & $\begin{array}{l}0.215^{* * *} \\
(2.941)\end{array}$ & $\begin{array}{c}0.073 \\
(0.729)\end{array}$ & $\begin{array}{c}0.097 \\
(0.849)\end{array}$ & $\begin{array}{c}0.133 \\
(1.482)\end{array}$ & $\begin{array}{c}0.194 \\
(0.696)\end{array}$ & $\begin{array}{c}0.348^{* * *} \\
(4.561)\end{array}$ & $\begin{array}{l}0.186^{* * *} \\
(2.589)\end{array}$ \\
\hline GovPercentage_lag & $\begin{array}{c}-0.075 \\
(-0.929)\end{array}$ & $\begin{array}{c}-0.172^{* * *} \\
(-3.076)\end{array}$ & $\begin{array}{c}0.011 \\
(0.150)\end{array}$ & $\begin{array}{l}-0.053 \\
(-0.523)\end{array}$ & $\begin{array}{c}0.044 \\
(0.061)\end{array}$ & $\begin{array}{l}-0.193 \\
(-1.521)\end{array}$ & $\begin{array}{c}-0.036 \\
(-0.503)\end{array}$ \\
\hline Leverage & $\begin{array}{l}0.535^{* * *} \\
(12.386)\end{array}$ & $\begin{array}{l}0.420^{* * * *} \\
(7.122)\end{array}$ & $\begin{array}{l}0.677^{* * * *} \\
(10.475)\end{array}$ & $\begin{array}{l}0.432^{* * * *} \\
(7.500)\end{array}$ & $\begin{array}{l}0.271^{* * *} \\
(3.678)\end{array}$ & $\begin{array}{l}0.541^{* * * *} \\
(6.224)\end{array}$ & $\begin{array}{l}0.540^{* * *} \\
(11.735)\end{array}$ \\
\hline FixedAssets & $\begin{array}{c}-0.166^{* * *} \\
(-3.419)\end{array}$ & $\begin{array}{l}-0.170 \\
(-1.215)\end{array}$ & $\begin{array}{l}-0.117^{*} \\
(-1.907)\end{array}$ & $\begin{array}{l}-0.187 \\
(-1.378)\end{array}$ & $\begin{array}{c}-0.273^{* * *} \\
(-5.973)\end{array}$ & $\begin{array}{c}-0.552^{* * *} \\
(-8.054)\end{array}$ & $\begin{array}{l}-0.110^{* *} \\
(-2.357)\end{array}$ \\
\hline LnAssets & $\begin{array}{c}-0.352^{* * *} \\
(-7.570)\end{array}$ & $\begin{array}{c}-0.360^{* * * *} \\
(-3.816)\end{array}$ & $\begin{array}{c}-0.299^{* * *} \\
(-6.316)\end{array}$ & $\begin{array}{c}-0.430^{* * *} \\
(-3.489)\end{array}$ & $\begin{array}{l}-0.295^{* * *} \\
(-13.859)\end{array}$ & $\begin{array}{l}-0.175^{* * *} \\
(-4.967)\end{array}$ & $\begin{array}{l}-0.353^{* * *} \\
(-8.211)\end{array}$ \\
\hline 2006 & $\begin{array}{l}0.119^{* * * *} \\
(6.971)\end{array}$ & $\begin{array}{l}0.181^{* * * *} \\
(2.899)\end{array}$ & $\begin{array}{c}0.083^{* * *} \\
(4.415)\end{array}$ & $\begin{array}{c}0.088^{* * *} \\
(9.169)\end{array}$ & $\begin{array}{l}0.100^{* * *} \\
(4.314)\end{array}$ & $\begin{array}{l}0.127^{* *} \\
(2.094)\end{array}$ & $\begin{array}{l}0.110^{* * *} \\
(6.394)\end{array}$ \\
\hline 2007 & $\begin{array}{l}0.067^{* *} \\
(2.294)\end{array}$ & $\begin{array}{l}0.244^{* * *} \\
(6.143)\end{array}$ & $\begin{array}{c}0.086 \\
(1.081)\end{array}$ & $\begin{array}{c}0.049 \\
(1.166)\end{array}$ & $\begin{array}{c}0.059 \\
(1.049)\end{array}$ & $\begin{array}{c}0.046 \\
(0.783)\end{array}$ & $\begin{array}{l}0.046^{*} \\
(1.681)\end{array}$ \\
\hline 2008 & $\begin{array}{c}-0.336^{* * *} \\
(-7.510)\end{array}$ & $\begin{array}{l}-0.222^{* * *} \\
(-11.096)\end{array}$ & $\begin{array}{c}-0.296^{* * *} \\
(-3.331)\end{array}$ & $\begin{array}{c}-0.399^{* * *} \\
(-6.379)\end{array}$ & $\begin{array}{l}-0.282^{* * *} \\
(-17.763)\end{array}$ & $\begin{array}{c}-0.403^{* * * *} \\
(-4.930)\end{array}$ & $\begin{array}{c}-0.344^{* * * *} \\
(-6.024)\end{array}$ \\
\hline 2009 & $\begin{array}{c}-0.152^{* * *} \\
(-5.941)\end{array}$ & $\begin{array}{c}-0.098^{* * *} \\
(-2.607)\end{array}$ & $\begin{array}{c}-0.109 \\
(-1.210)\end{array}$ & $\begin{array}{c}-0.212^{* * *} \\
(-4.123)\end{array}$ & $\begin{array}{l}-0.106^{*} \\
(-1.943)\end{array}$ & $\begin{array}{c}-0.189^{* * *} \\
(-3.521)\end{array}$ & $\begin{array}{c}-0.164^{* * * *} \\
(-6.940)\end{array}$ \\
\hline$B H$ & Yes & Yes & Yes & Yes & Yes & Yes & Yes \\
\hline BHO6 * Crisis Years & Yes & Yes & Yes & Yes & Yes & Yes & Yes \\
\hline Firm FE & Yes & Yes & Yes & Yes & Yes & Yes & Yes \\
\hline$N$ & 18,854 & 2,606 & 9,265 & 5,957 & 1,063 & 3,350 & 13,650 \\
\hline$R^{2}$ & 0.438 & 0.463 & 0.411 & 0.479 & 0.392 & 0.445 & 0.440 \\
\hline
\end{tabular}

